\title{
ФІЛОСОФІЯ ЯК НЕОБХІДНА ПЕРЕДУМОВА І МЕТА ОСВІТИ ТА ВИХОВАННЯ
}

\author{
Г.А.Балута
}

\begin{abstract}
Философия есть только идея возможной науки, которая нигде не дана in concreto, но к которой мы пытаемся приблизиться различными путями.
\end{abstract}

\section{И. Кант}

Успішне реформування системи освіти відповідно до нових цивілізаційних запитів має низку проблем, вирішення яких потребує оновлення і переоцінки навчально-методичної бази предметного поля у системі вищої освіти, у якому філософія - i це не викликає жодного сумніву - посідає одне з чільних місць, незалежно від специфіки чи фахової орієнтації навчального закладу. Навіщо треба вивчати філософію? 3 цього «класичного питання» починаються майже всі підручники, наукові статті, методологічні дослідження, у центрі уваги яких - філософія. Протягом довготривалого часу проблема актуальності вивчення цього «загадкового» предмета не може залишити байдужими ні прихильників філософії, ні її опонентів. Як правило, ми не усвідомлюємо того, що філософія пронизує не тільки наше суто професійне життя, a $€$ також часткою нашого життєвого світу, дозволяючи підійти до вирішення складних внутрішніх конфліктів між особистим і загальнолюдським, інтересом і обов'язком, природнім егоїзмом і моральною свободою. Особисте вирішення такого роду конфліктів так чи інакше вибудовується у інтерсуб'єктивному руслі, відкриваючи більш глибоке розуміння безумовної єдності людини і світу, неймовірну складність і несподівану простоту цього зв'язку. Будь-яке питання, що торкається

Актуальні проблеми духовності 
фундаментальних буттєвих ситуацій є філософськими у своїй суті, i кінцеві результати філософського пошуку можуть приводити як до бажаних перемог, так і до серйозних цивілізаційних деформацій на шляху історії. Історико-філософський контекст та подальшу філософську аналітику можна мислити у формі своєрідної теоретичної апробації ймовірних наслідків тієї чи іншої ідеї, яка передує практичній меті. Інакше, без філософії історія втрачає розумний сенс.

Особливістю сучасної доби є прискорена динаміка соціокультурного розвитку, розширення інформаційних горизонтів, переструктурування інтерпретативних схем світорозуміння - все це вимагає нової оцінки у осмисленні того факту, що прагнення Україною партнерства 3 європейськими державами у царині освіти, рівноцінності дипломів про освіту та рівня професійності не можуть реалізуватися без контексту перспективного розвитку дисциплін філософського циклу.

Не є перебільшенням сказати, що розвинене філософське мислення, як мислення критичне і незаангажоване загалом, супроводжує найбільш високі творчі і кар'єрні злети, стоїть у основі фундаментальних наукових поворотів і торкається приватних справ у якості показника рівня загальної освітньої культури і надійного засобу у вирішенні складних життєвих кутів. Важливою обставиною є також те, принаймні у філософській теорії, що успіх нації може визначатися не розвитком матеріально-економічних систем, з яких «виводяться» інтелектуальні структури суспільства, а розвитком соціокультурної реальності, сутнісних духовних констант як стратегій морального прогресу, який розглядається як бажаний «факт». I перш за все, це збереження універсальних та етнічних цінностей, мінімізація соціальної аномії, опір етнічній асиміляції та тенденції до генетичної деградації. Присутність зазначених соціальних «констант» визначають успіх нації у її розвитку. Вектор морального прогресу вибудовується на основі філософського обгрунтування необхідності соціальної етики, що передбачає наявність філософського предметного поля, тобто якісного забезпечення викладання філософських дисциплін і їх популяризації.

Політична діалектика, часто проявляючи себе у безпредметних щодо загальної справи зіткненнях амбіцій, особистих чи групових інтересів та намагань, як у кривому дзеркалі відбиває високе благородство філософів і святих - Гаутами, Моїсея, Ісуса. Відкритість філософії, яка не витіснила зі свого кола навіть тих, хто мислив себе філософом, виходячи з кар'єрних мотивів чи з причини ураженого самолюбства, що $є$ досить типовим у інтелектуальних колах, не може не викликати інтересу і бажаного наслідування як з боку науковців, так і полі- 
тиків. «Відійди, не затуляй мені сонця», - сказав Діоген богорівному Олександру, вихованому самим Арістотелем і не опинився за гратами. «Якщо такого і не було, історія розкриває чудовий зразок етичного філософського братсва, де $\mathrm{i}$ «Боги» $\mathrm{i}$ «кесарі» отримують свою частку справедливості».

Окремо слід згадати про взаємозв'язок релігії, філософії і науки. Б. Расел небезпідставно визначив філософію як нейтральну землю між наукою і релігією. Філософська думка знаходиться у площині філософської віри, яка пролягає між науковою і релігійною вірами. Чи не тому інтелект Р. Декарта, Г. Лейбніца, Б. Паскаля, І. Ньютона, І. Канта сягав інтуїтивного передчуття необхідності «схилити розум перед вірою»? I саме тому «бунтівний дух» Л. Фейербаха, Ф. Ніцше, З. Фрейда, успадкував прометеївську ідею богорівності людини, яка так мало знає про свою могутність і силу. Тут визначається і сенс філософії-стати зброєю проти темряви і страху, проти фальшу і несправедливості. Так, К. Ясперс поглянув на філософію з боку її терапевтичної функціїдопомогти людині стати самою собою. Отже, філософія не є наукою, предмет науки завжди обмежений, вона $є$ інструмент самої душі.

Саме філософія дозволяє звести до єдиного цілого спектр концептуальних і методологічних передумов, на яких засновується науковий чи будь-який інший проект. На відміну від казуальної методології «наук про природу», що дозволила пояснити факт чи явище, філософія втілила герменевтичну методологію і її провідний принцип - принцип розуміння як інтуїтивне схоплення ситуації, у яку включено як факт, так і «пізнавальну ситуацію» самого спостерігача. Філософія одна 3 перших відомих наук зруйнувала дитячу ілюзію людства: у світі нічого не існує самого по собі. На питання: у яких вимірах приховується причина такого зв'язку, - першою з наук має відповідати виключно філософія.

Як специфічний фундамент культури, наука виявилась включеною в коло духовних феноменів і у своєму розвитку отримала новий імпульс на шляху до методологічної можливості конвергенції природничих та гуманітарних наук. Досить вразливе щодо скепсису з боку класичної науки питання такого «альянсу» було обмірковане І. Пригожиним та I. Стенгерсом у позитивному рішенні. Авторитет філософськонаукової еліти, широке коло методологічних надбань та практичної перспективи філософського пошуку дозволили філософії заявити про себе як про «теорію здорового глузду», яка не суперечить принципу реальності, що домінував у науці і цим підносив її над філософією, а, навпаки, поглиблює його на підставі єдності двох пізнавальних моделей, 
у яких абсолютне не протистоїть відносному, а відносне не «розмиває» абсолютне у модусі науково-філософської аргументації. Феноменологічні і лінгвістико-соціальні підходи продемонстрували факт «топологічної багатомірності простору», що зумовило вищезазначений методологічний вибір.

Філософське мислення, як мислення професіональне, незалежно від його фахової спрямованості, демонструє справжній демократизм думки, невичерпні евристичні можливості, гартує мужність, інтелектуальну культуру та конструктивний нонконформізм - якості, необхідні для інноваційного розвитку та якісного потенціалу будь-якої професійної галузі. Звичайно, це характерно і для науки, яка все частіше орієнтує свій пошук у бік філософських інтерпретацій досліджуваних нею явищ. Все це потребує яскравих особистісних рис, оскільки науковий консенсус має не суто когнітивний, а когнітивно-вольовий характер. «Це означає, що проблема істини - це не тільки справа досвіду, розуму, але і волі, - відзначають Ф.В.Лазарєв, С.А.Лебедєв, - саме завдяки когнітивній волі припиняється нескінченний регрес в емпіричному і теоретичному обгрунтуванні наукової концепції і долається завжди присутня недовизначеність та імпліцитність будь-якого знання. Саме когнітивна воля лежить в основі прийняття суб'єктом пізнання рішення про істинність того чи іншого фрагменту наукового знання» [8, с. 107]. «Як мало йдеться про «філософський подвиг», здійснений Коперніком і Кантом, Фрейдом і Вітгенштейном, ціна якого «драма особистого життя», комфорту життя для себе, «яке проживає більшість».

Невичерпність позитивного потенціалу філософії дозволяє розглядати її як один із надійних засобів формування естетичної свідомості. Інтенційність як фундаментальна ознака свідомості передбачає «внутрішнє знання прекрасного» і настійний потяг втілити його у життя. Розвинене філософією «почуття міри і досконалості» має надзвичайну соціальну цінність, справляючи істотний вплив на якість виконаної роботи, що у свою чергу ясно вимальовує такі необхідні особистісні риси як відповідальність і придатність до праці. Чи змогли б греки досягти небачених надалі цивілізаційних висот, якщо не мали б виняткової концепції краси, підведеної під фундаментальну філософську основу. Піфагор, Сократ, Платон, Аристотель - присвятили ідеї прекрасного свої духовні сили, виходячи з неї як форми і самої можливості пізнавальної ситуації. Краса форми і краса душі виявилися настільки тісними, що дозволили усвідомити закономірний зв'язок між душевними і творчими здібностями, а також підвели до розуміння моральності фі- 
лософії, яка поза нею перетворюється у дуже небезпечну річ. Необмеженість продуктивної уяви породжує «філософські монстри», генератори морального зла. У проясненні «закритості» філософії у давньому минулому навряд чи можна обійтися тільки фактом її елітарності, виключивши при цьому їі етичні аспекти. Упродовж історії філософія як необмежена система знань змикалася з магією, єрессю, випробовувалась навіюваністю хисткого людського серця. «Філософ» Фауст звертається до магії, бо душі його тісно. Перевищити людське - ось та спокуса, що змушує забути про нього в обмін на дорогоцінне знання. Така проекція не залишає сумніву: творцем такого повороту думки міг бути тільки геній. Філософське надсприйняття як відкритість світу врівноважується внутрішньою силою, онтологічною міцністю. Таємницю геніальності Гете можна сформулювати трьома словами - «це велика піддатливість при великій волі» [5, с. 146-147]. Практика як синтез пізнання і творчості буде мати життєстверджуючі наслідки лише в тому випадку, коли «модус» пізнавальної ситуації не виходитиме за межі буття - укоріненого «знання» добра, що зводить до єдиного спектр ніби-то окремих реальностей внутрішнім проривом людської свідомості, яка повністю усвідомлює свою відповідальність.

Звертаючись до проблем пов'язаних з актуальністю викладання філософії та значущості цього предмета у сфері виховання, варто відзначити плідну працю філософської національної еліти, яка як професійне угрупування відіграє помітну роль у суспільстві, залишаючись впливовим осередком на фоні інших наукових та соціальних спільнот і продовжує функціонувати як необхідна соціокультурна константа, всупереч скепсису, непрофесіоналізму і помітними ціннісними викривленням, які перебудовують державу з «держави патріотів» на «державу дикунів». Доктор філософії, професор Г. Горак зазначає: «Філософія здатна до повноцінного функціонування в суспільстві, особливо в наш час, якщо вона ефективно користується засобами донесення своїх ідей до свідомості суспільства загалом» [3, с. 13]. Однак, на її думку і $з$ цим погодиться кожен небайдужий - філософія в Україні «потерпає» через відсутність фахівців високого рівня. «Суспільству потрібен філософський Олімп, на якому зосереджені фахівці найвищого гатунку, здатні до генерування фундаментальних ідей», - відмічає Г. Горак $[3$, с. 13]. Все ж погодимося, що представники філософського Олімпу в Україні є. І серед провідних завдань філософської спільноти - довести суспільству, що філософія - це найбільше благо для держави.

Доктор Г. Горак не відмовляється від ідеї популяризації філософії, так як вважає, що «філософія дуже втрачає від того, що оберігає свою 
недоступність пересічному смертному» [3, с.13]. Увага та зусилля вітчизняних фахівців не оминули і цю важливу проблему. Створюється оригінальна навчально-методична література, розробляються впливові освітньо-виховні концепції. В контексті вищезазначеного можна назвати «Практикум з філософії» (автори - В.Ф. Сухіна, К.В. Кислюк), легкий для розуміння та неповторний у своєму викладі, навчальний посібник «Історія філософії. Проблема людини та їі меж» (автори Н. Хамітов, Л. Гармаш, С. Крилова) та ін.

Сьогодні теоретична філософія перетікає у русло філософії практичної, яка намагається вирішити складні і «вічні» питання у вигляді пошуку аксіоматики людського буття і її актуальність насправді $€$ більш значущою, ніж це здається на перший погляд. Проблематику морального виховання, що здійснюється засобом філософії і філософування актуалізують вітчизняні і європейські мислителі [4].

Стверджуючи етичні цінності, практична філософія «відновлює» поняття гідного життя, підзабутого у гонитві за владою, грішми і славою - «трьома китами» майбутнього соціального успіху i, врослих у грунт соціальності, ціннісних пріоритетів. Навряд чи можна знайти більш небезпечні для здорового суспільства тенденції, ніж гідність, вимірювана предметами і масштабами, байдужа до гідності інших. Моральна автономія людини по відношенню до природної обумовленості дозволила людству отримати шанс «зрозуміти життя» не як стихійне самовідтворення, а хистку у своїй «предметній» видимості онтологічну форму його можливості. Сократ, Кант, Маркс, Швейцер - всі вони подарували людству свої варіанти усвідомлення загального добра, помітно зійшовшись у «принципі гідного життя». «Життя, на думку Сократа, може бути виправдане тільки з точки зору можливості пізнання і здійснення своєї максимальної моральної достовірності і абсолютної моральної якісності» - так інтерпретує етичний ідеал філософа М.Л.Клюзова, розглядаючи його ідеї як пролог європейського етичного мислення і програму його розгортання в універсальне раціонально-моральне життєствердження і життєвченння [7, с.65]. Упродовж останнього часу зневага до філософії, породжена «зачарованістю» матеріальним початком речей та світоглядними уніфікаціями, 3 претензіями на викриття її як псевдопредмета чи смислового нонсенca, стає вже ознакою «старого жанру» і попри всі соціально-економічні негаразди свідчить про реальність духовно-оздоровчих процесів, що протікають в Україні.

Однак, загальновизнано, що викладання саме філософії, а не будьякого іншого предмета потребує не тільки суттєвої і довготривалої фа- 
хової підготовки, а й підготовлених до опанування предметом студентів. I це викликає деяке роздратування з боку останніх, які б не були звичайними студентами, якби всі до одного вкрай сумлінно працювали. Лише поступово студенти починають розуміти, що високий бал 3 історії чи іноземної мови не є гарантом такого успіху у філософії, яка потребує серйозної уваги і окремого хисту. Як спосіб особистісної самопрезентації, вона, скоріше, не засвоюється, а персонально продукується. Вона не залишає осторонь ні студента, ні політика, ні науковця, ні звичайну людину, яка у своїй повсякденності мало замислюється над сенсом буття чи достатніми підставами нової наукової теорії. Досить ще розповсюджені і звичні всякому філософу скептичні суперечки про значущість філософії як окремого феномена і специфічного навчального предмета свідчать тільки про одне: світоглядну неповноцінність i брак розумової культури, без якої не $є$ самодостатніми і можливими ні наукова теорія, ні художня творчість. Філософія історії, яка розгортається як широка панорама культурної полеміки дозволяє відчути i зрозуміти це у численних прикладах філософських дискусій, у яких навряд чи було місце матеріальному егоїзму і приватному інтересу, позбавленому устремлінь до спільної мети.

На думку Н. Хамітова, виклад історії філософії має низку труднощів: по-перше, проблема вибору авторів та автентичне прочитання філософського тексту [5]. Від себе зазначимо, що проблема інтерпретації та перекладу філософської спадщини становить реальну трудність, яку необхідно подолати. Образ «філософа» передбачає не тільки фахову придатність, а це повсякденна і важка розумова праця, а й якісне знання історії, міфології, логіки, психології, лінгвістики, бездоганне володіння мовами, що у своїй більшості демонструють представники вітчизняних філософських кіл. Традиційно склалося, що у самих своix витоках філософія організована як універсальна наука, яка вимагає універсальності і від її представників.

По-друге, залишається нез'ясованою проблема визначення філософiї, i тут ми знову не можемо обійтися без метафор чи аналогій, намагаючись хоча б приблизно визначити те, чого немає конкретно. Втім, можна ще раз нагадати думку I. Канта, який писав: «Філософія є наукою про відношення всякого знання до сутнісних цілей людського розуму (teleologia rationis humanae)» [6, с. 436]. 3 точки зору філософа, суттєві цілі ще не означають вищих цілей, тому вищою може бути лише одна мета (за умови досконалої систематичної єдності розуму) призначення людини. Дослідження такої мети - завдання моральної філософії. Саме через це у давні часи образ філософа співвідносився 
з образом мораліста. «Навіть тепер зовнішній вигляд самоопанування, отриманого за допомогою розуму, дає привід за аналогією назвати людину філософом, хоча б його знання було обмеженим» [6, с. 436].

По-третє, трудність викладу зумовлена врахуванням «логіки спадкоємності і взаємозв'язку філософських вчень» (Н. Хамітов). Філософія і її історія - це грандіозний спектакль сміливих гіпотез, поглядів, ідей, їх критики та поновленої реабілітації. Ця особливість впливає на структуру викладу, що не повинен розгубити жодної філософської деталі. Культура викладу матеріалу підручника, як правило, повинна передбачати авторський коментар, який пояснює внутрішню логіку автора. Наприклад, відомий курс «Історія філософії» авторами якого $є$ Г. Скірбекк та Н. Гільє репрезентує своє бачення історії філософії «в контексті проблематики природного права [natural rights] і експансії природознавства і наукової раціональності», намагаючись уникнути «відбитків життєвого світу»- особливостей наукової і педагогічної кар'єри авторів, їх наукових інтересів чи культурних орієнтацій [9]. Наприклад, Н. Хамітов починає свій виклад з обгрунтування наскрізної для курсу теми-проблеми людини та її меж, викладеної під кутом авторського бачення, визначеного ним як метаантропологія [5]. Подані приклади ілюструють два різні смислові підходи, однак для обох, поза відмінністю змістів та обсягів, є характерним стиль, що об'єднує автономне рішення з універсальністю філософської культури, а це дозволяє вести діалог у заздалегідь визначеному і тому зрозумілому руслі. Тут можна зауважити, що зміст філософської культури має значно ширші виміри. Власне, філософська культура як культура свідомості $є$ особливою символічною реальністю, у якій перетинається множина можливих інтерпретацій феномена, заданих часом і незалежність самого феномена. Така модель змушує бути обережним у тлумаченнях, які легко обертаються на «гіперсимволізацію» прояснення неусвідомлених вторинних смислів, які затьмарюють чи «скасовують» первині суті. Розглядаючи специфіку філософування М. Мамардашвілі, С. Вєковішина актуалізує методологічну тему, вказуючи на необхідність такої обережності символічних інтерпретацій i подає зразок як міркував про наслідки подібної діяльності відомий мислитель: «В історії це завжди призводило до звільнення руйнівних сил людського розуму і в кінцевому підсумку до трагічних для людини наслідків - атеїстичного шаленства, «культурних революцій», тоталітаризму, фашизму тощо» [2, с. 19-20].

Необхідну і вельми складну тему філософської методології та методологічної коректності розгортає доктор філософських наук, професор 
М. Булатов. Довільність у методології майже на всіх рівнях філософського функціонування, на жаль, вибудовується у напрямку від органічної єдності до еклектицизму. «Останній $є$ найхарактернішою рисою сучасного стану філософії в Україні», - підсумовує автор у своїй статті «Про методи філософування» $[1$, с. 29]. Такий стан речей фактично вимагає обов'язкової методологічної обізнаності та ретельної аналітичної роботи, пов'язаної як з філософським пошуком, так і викладом філософського матеріалу.

Підсумуємо наші міркування: викладання філософії в тому вигляді як ми його маємо потребує певної переоцінки з боку представників фаху і з боку студентства. Введені у шкільну практику курси «Основи філософських знань», «Етика», «Культурологія» не у повній мірі готують світоглядний грунт для розуміння необхідності філософських знань і подальшого їх розвитку. Виправленню такої ситуації повинні сприяти постійні зв'язки шкільних та вузівських кадрів, пожвавлення роботи шкільних філософських груп, гуртків, додаткових курсів.

Як було зазначено, успішне функціонування філософії вибудовується на фоні цілераціональної єдності філософської спільноти, яка $є$ відкритою для реалізації наукового консенсуса. «Професійна політика» не повинна супроводжуватися стихійним підбором кадрів, а намагатися зберегти ті інтенції, які разом взяті могли відповідати «образу філософа», складеного філософською традицією з поміркованості, мужньості та мудрості. На жаль, останнім часом філософія із справедливої науки перетворюється у «набуток обраних», у яких своє розуміння філософії і головне - себе у ній. (Втім, так було завжди, якщо відкинути бажану раціональність філософського порозуміння, яка, на превеликий жаль, таки має романтичний присмак).

Нагромадження філософських проблем, помітний відхід від схоластичних міркувань, відмова від з'ясування «технічного» горизонту філософії ставить у центр уваги «проблему методу». Як правило, курс викладання філософії обмежується коротким описом методів у розділі «Теорія пізнання» і мало супроводжується коментарями, що фіксують методологічний шлях відбору найбільш цінних філософських ідей. I в цьому є недоліки об'єктивного характеру. Професійний філософський дискурс і справді знецінюється без методологічної організації, того показника «технічного вишколу», без якого жодна нова ідея не варта того, щоб стати філософською. Тому у колі проблемного поля залишаються методи філософування, які потребують і окремої уваги і ясної систематизації: методів дослідження, методів викладу, зокрема лекційних, та методів практичної роботи, яка включає предметний 
діалог та перевірку власне філософських знань студента. Вагому роль у такій методологічній системі повинні відігравати і виховні методи, які орієнтують думку до самостійного пошуку і власної оцінки явищ у «форматі» практичної філософії, прогнозу можливих наслідків інтелектуальної ідеї та співвіднесеної з нею дії. Значний обсяг філософського матеріалу, обмеженість аудиторних годин справді утруднюють такі вагомі форми реалізації навчального процесу як перевірка прочитаних першоджерел, тематики самостійного опрацювання, аналіз прочитаної додаткової літератури. Це не простий недолік, адже у недалекому минулому філософські студії Києво-Могилянської академії за короткий проміжок історії надбали справжній філософський капітал і серйозний кадровий ресурс, що дозволило вписати її феноменальний досвід у найбільш яскраві фрагменти української історії. Києво-Могилянська академія засвідчила початок історії української академічної філософії як філософії європейської стилістики та європейського звучання, вона ствердила інтелектуальну силу і цивілізаційну перспективу української нації, що здобула визнання в Європі. Як показує така практика, філософія не вимагає безглуздої поспішності, а, навпаки, протистоїть їй за своєю суттю.

Отже, філософія допомагає відбутись, реалізуватись як свободна особистість, що з усіх можливих знань володіє найціннішим - стати людиною, а вже згодом і професіоналом. Як відомо, А. Ейнштейн свого часу заявив, що як вчений у більшій мірі відбувся завдяки Достоєвському, ніж Гаусу. Чому могли навчити геніального фізика твори російського письменника-філософа? 3 точки зору Ф.В. Лазарєва та С.А.Лебедєва, відповідь може бути такою: «Усвідомленню свободи і відповідальності у якості родових властивостей (атрибутів людини), в тому числі і у якості пізнаючого суб'єкта по відношенню до пізнаваної ним дійсності. В силу вродженої людині свободи, з одного боку, і необхідності діяти - з іншої, вона часто знаходиться у ситуації вибору, коли необхідно час від часу «переступати межу», що відокремлює минуле і майбутнє, і приймати рішення в умовах завжди неповної визначеності зі всіма випливаючими звідси наслідками у майбутньому за прийняте рішення» [8, с. 107]. Отже, філософський пошук цінний ще тим, що наближає до етичної мети - усвідомлення необхідності розумної свободи, яка завжди виходить за межі природного егоїзму. Навряд чи можливо викладати і опановувати філософію так, як вивчають математику чи навчаються правилам етикету. В цьому смислі філософія $\epsilon$ тільки ідея можливої науки, а до ідеї можна лише нескінченно наближатись до того часу, «поки не буде відкрита єдина, дуже заросла 
чуттєвістю стежка і поки людині не вдасться, наскільки це дозволено їй, зробити до сих пір невдалу копію рівною взірцю» [6, с. 435]. I поки такий взірець залишається за межами можливостей інтелекту, але ж у межах етичної свідомості, можна навчати лише філософуванню, а не філософії.

Таким чином, знайомство з філософією збігається з процесом виховання нею і має низку визначених нами характерних вимірів, що роблять цей предмет як привабливим, так і не зовсім досяжним у смислі повноти його засвоєння, визначення предметності чи критеріїв об'єктивності. I труднощі, пов'язані з викладанням філософії можуть бути подолані за умови загальної зацікавленості поруч з набуттям i прикладенням цілісної методології. Студенти і всі, кому небайдуже їхнє майбутнє, не повинні відразу ж дратуватися при слові «філософія», а набути великого терпіння, щоб визнати внутрішню красу цього предмета - його гармонію і гуманістичну цінність, справжній демократизм і рідкісну елітарність, які проявилися у знаменітій самоіронії Сократа. «Я знаю, що нічого не знаю» - сказав найглибший з мудреців. Сократ, на відміну від софістів, не видавав себе за мудреця, якому все відомо і який навчить великої премудрості. Це був тільки діалог, де двоє отримували рівні права проявити себе. Чи не лукавив великий мудрець і великий вчитель? Сократу колись наснився сон, мовби він тримає маленького лебедя, а той раптом вкрився пір'ям і полетів. Наступного дня він зустрів Платона і сказав, що це і $є$ його лебідь. Якраз тут стирається межа між любов'ю і мудрістю, а це під силу далеко не кожному із тих, хто «любить мудрість».

\section{1 Бібліографія}

[1] Булатов М. Про методи філософування // Філософська думка. 2004. - № 2. - C. 15-30.

[2] Вековішина C. Проблема феноменів свідомості в творчості М.К. Мамардашвілі // Філософська думка. - 2000. - № 4. - С.321.

[3] Горак Г. Філософська спільнота як соціальна, наукова, соціальнопсихологічна структура // Філософська думка. -2004 . - № $1 .-$ C. 3-14.

[4] Делл'Аста А. Виховання та дійсність // Філософська думка.2004. 一№ 2. - С. 114-125. 
[5] Iсторія філософії. Проблема людини та їі меж /під редакцією Н. Хамітова/. - К.: Наукова думка, 2000.

[6] Кант И. Критика чистого разума. - Симферополь: Реноме, 1998.

[7] Клюзова М.Л. Этика как апология жизни // Вопросы философии. - 2005. - № 10. - С. 55-68.

[8] Лазарев В.Ф., Лебедев С.А. Проблема истины в социально-гуманитарных науках: интервальный подход // Вопросы философии. -2005 . - № 10. - С. 95-116.

[9] Скирбекк Г., Гилье Н. История философии: Учеб. пособие для студ.высш. учеб. заведений /Пер. с англ. В.И. Кузнецова; под ред. С.Б. Крымского. - М.: Гуманит. изд. Центр ВЛАДОС, 2001. 